\title{
Zinc Finger Protein ZIC 2
}

National Cancer Institute

\section{Source}

National Cancer Institute. Zinc Finger Protein ZIC 2. NCI Thesaurus. Code C75541.

Zinc finger protein ZIC 2 (532 aa, $55 \mathrm{kDa}$ ) is encoded by the human ZIC2 gene. This protein plays a role in both transcriptional regulation and brain development. 